\title{
Neural networks at the human mind: translator's hidden layers Anna Aguilar-Amat ${ }^{1}$ \\ Department of Translation and Interpretation and East Asian Studies (DTIEAO), Autonomous University of Barcelona, 08193 Barcelona (Bellaterra), Spain \\ 1anna.aguilar-amat@uab.cat
}

Keywords: Conceptual diagrams, specialized translation and post-editing, neural network

\begin{abstract}
This article is based on training process for students to become specialized translators and post-editors. Any language mediator working within specialized communication may use a graphic representation to outline the contents of a text in a particular domain. The aim of this graphic depiction is to draw mental structures that distinguish the main concepts from the subordinates, while linking them to their linguistic referents of the different languages. This conceptual diagram can be seen as a neural network: there is an input layer (terms in a text), a hidden layer where the student comes into the upper ordinate and subordinate layers and hierarchies (mind), and an output layer (the diagram bridging equivalences). Young students at Translation Faculty must front the fact that it is not only language skills what they need, but an objective conceptual diagram on domains they have no previous idea of the subject.
\end{abstract}

\section{Introduction}

Outlining is a common activity in learning processes, because actions and conceptual hierarchies (creating structures from linked concepts) help us to understand and represent a given approach to reality. Translating a specialized text presents the particular challenge to go from a verbal and idiomatic representation to a conceptual representation and build a new text. The goal is to become a 'pseudospecialist' able to handle specialized content and produce a coherent target text.

Assuming that there is no single way from the point of view of the expert, the language mediator (i.e. a translator, pots-editor) will have to deal with the different approaches and, in addition to this, they will have to cope with all the possible differences and variations between the two languages (the two mind systems) involved in the translation.

As Faber [4] states, there is a dynamism in the human perception of expertise and this dynamicity may not have been taken into account. Once language mediators identify different conceptual systems, then their minds should decipher the hidden relations between the systems. So specialized translation process can be seen as neural networks where most of the work is done underneath at a conceptual level.

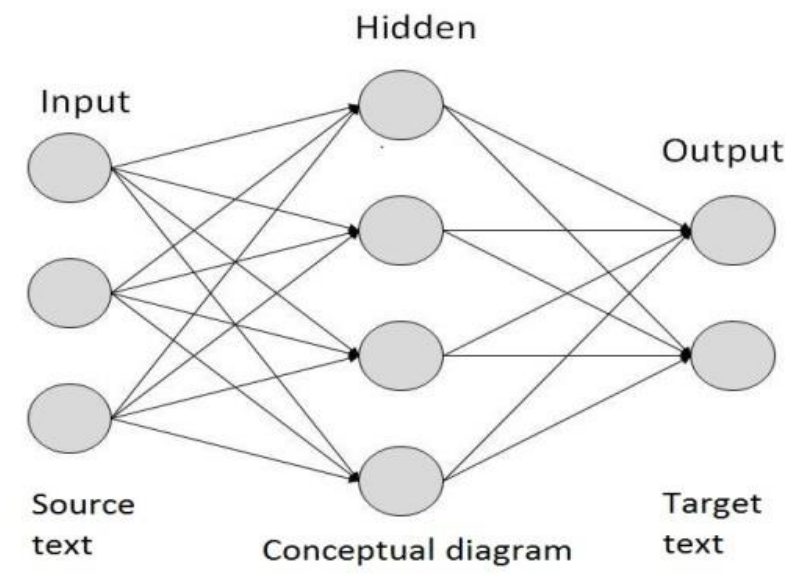

Fig. 1 Specialized translation process 


\section{Graphic representations: types of schemes}

A 'scheme' (gr. skhema = shape) or 'diagram' (gr. dia (through) and grama (representation)) simplifies and highlights the deep dynamics in contrast to the surface "noise" and highlights the different connections between concepts. From the organon in Aristotelian logic [2], several types of schemes or diagrams have been used in literature:

Conceptual maps: Developed by Joseph D. Novak [5] and his research team at Cornell University in the 1970s, this term has become a popular method in education for constructing schemes during the learning process. It is used as a graphical tool when organizing and structuring knowledge. This creation process begins by making a list of concepts and then grouping the concepts according to which relationship is logically next.

Flowcharts: A flowchart is a type of diagram that allows us to combine concatenated actions and determines individual results. It represents an algorithm, workflow or process. Flowcharts are determinative process diagrams in a tree shape connecting some of their nodes through alternative options to reach a final state or the solution to a problem.

Mind maps: Also known as radial diagrams and conceptual networks consist of a central concept around which 5 to 10 related ideas are drawn. From each of these related words another 5 to 10 related ideas are drawn in turn. Mind maps graphically show the expansion of a concept, its semantic and conceptual distribution, i.e. all the concepts that relate to the one located at the centre of the diagram.

Tree diagrams: A tree diagram or tree structure consists of $n$ steps, where each step has a finite number of ways in which it can be carried out. The chart resembles an upside down tree, with the "root" at the top and the "leaves" at the bottom. It is a diagram of possible combinations in making probability calculations.

Tree diagrams describing a domain: tree diagrams are approaches to subject areas by describing their boundaries in reality through a series of logical relationships. Specific terms are subordinated hierarchically to ad-hoc abstracts generic ones. I.e. The Universal Decimal Classification (UDC); the Code of Biological Nomenclature.

\section{Hidden layers and common mistakes by trainee translators}

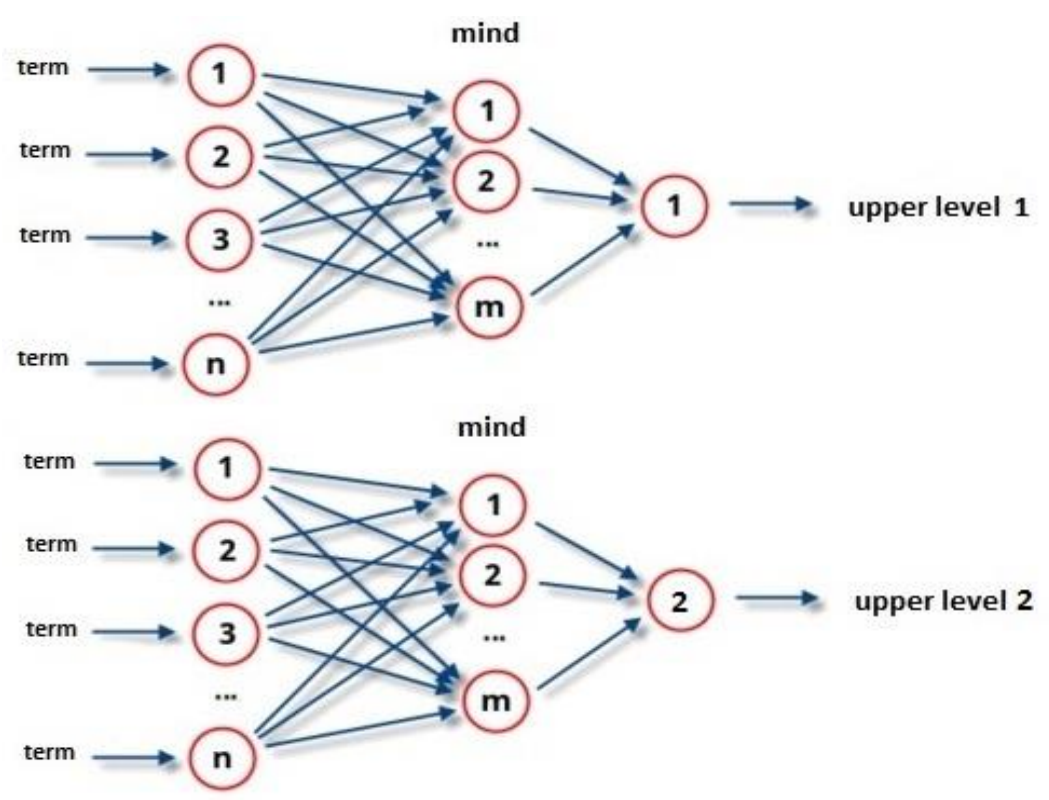

Fig. 2 From terms to upper levels 
We present the following overview of what we consider "the hidden layers" that allow trainee students to face challenges to achieve a useful diagram. Table 1 shows a diagram coming from failure (F) to a useful output after 'hidden layers' (OK).

Table 1. Compared output diagrams

\begin{tabular}{|c|c|}
\hline $\begin{array}{l}\text { PETROL ENGINE } \\
\text { SYSTEMS (F) } \\
\text { 1. Fuel } \\
\text { 1.1. Parts } \\
\text { 1.1.1. Fuel injectors } \\
\text { 1.2. Actions } \\
\text { 1.2.1. Combustion } \\
\text { 1.2.2. Autoignition } \\
\text { 1.2.3. Compression } \\
\text { 1.2.4. Engine knock } \\
\text { 2. Air (Oxygen) } \\
\text { 2.1. Parts } \\
\text { 2.1.1. Air intake } \\
\text { manifold } \\
\text { 2.1.2. Air filter } \\
\text { 3. Oil } \\
\text { 3.1. Parts } \\
\text { 3.1.1. Oil galleries } \\
\text { 3.1.2. Oil filter } \\
\text { 3.1.3. Oil pan } \\
\text { 3.1.4. Oil pump } \\
\text { 3.2. Actions } \\
\text { 3.2.1. Lubricate } \\
\text { 4. Cooling } \\
\text { 4.1. Parts } \\
\text { 4.1.1. Thermostat } \\
\text { 4.1.2. Radiator + fan } \\
\text { 4.1.3. Antifreeze }\end{array}$ & $\begin{array}{l}\text { 1. Components of a petrol engine system } \\
\text { es árbol de levas / fr abre à cames / de Nockenwelle / en camshaft } \\
\text { es pistón / fr piston / de Kolben / en piston } \\
\text { es cárter / fr cárter / de Ölwanne / en crankcase } \\
\text { es cilindro / fr cylindre / de Zylinder / en cylinder } \\
\text { es catalizador / fr pot catalytique / de Katalysator / en catalytic converter } \\
\text { es biela / fr bielle / de Pleuelstange / en connecting rod } \\
\text { es bujía / fr bougie / de Zündkerze / en spark plug } \\
\text { es cigüeñal / fr vilebrequin / de Kurbelwelle / en crankshaft } \\
\text { es carburador / fr carburateur / de Vergaser / en carburetor } \\
\text { es culata / fr culasse / de Zylinderkopf / en cylinder head } \\
\text { es válvula de admisión / fr soupape d'admission / de Einlassventil / en intake valve } \\
\text { es válvula de escape / fr soupape d'échappement / de Auslassventil / en exhaust val } \\
\text { 2. Combustion processes in a petrol engine system } \\
\text { es cámara de combustión / fr chambre de combustión / de Verbrennungskammer } \\
\text { combustion chamber } \\
\text { es admisión / fr admission / de ansaugen / en intake } \\
\text { es compresión / fr compression / de verdichten / en compression } \\
\text { es explosión / fr combustion / de arbeiten / en power } \\
\text { es escape / fr échappement / de ausstoßen / en exhaust } \\
\text { 3. Components of a petrol engine-cooling system } \\
\text { es radiador / fr radiateur / de Kühler / en radiator } \\
\text { es termostato / fr thermostat / de Thermostat / en thermostat } \\
\text { es líquido anticongelante / fr antigel / de Frostschutzmittel / en antifreeze }\end{array}$ \\
\hline
\end{tabular}

After training translator's students during a decade $[1,3]$ we observed the most frequent challenges at the hidden layers while building a conceptual diagram are:

1. Locate a term in a single section (a term cannot be located in two different branches at the same time).

2. Postpone the definition of the term (do not use the domain tree as a system for definitions).

3. Take into consideration the classifications already done by experts on the field (top-down understanding of concepts) but allow the bottom-up flow arise from terms.

4. Avoid 'epistemological inflation': do not leave empty branches acting like hyperlinks inside other hyperlinks. (Empty subsections will be lost when describing the concept in isolation).

6. Avoid 'gnoseological inflation'. The greater the depth of subsections (i.e. subdivisions of branches), the harder it will be to serve as a bridge between different languages and cultures.

7. Avoid the use of ellipses at branches wording. Any section and subsection of the domain tree must as complete and self-descriptive as possible to stand isolation.

8. Avoid the 'sweeping under carpet' effect. Do not use non-specified branches like 'Others' or 'Miscellaneous'. 
9. Grammatical aspects should not be taken into account for conceptual purposes. Avoid branches called 'Nouns', 'Verbs' or 'Proper names'.

10. Avoid the 'matryoshka doll' effect. Do not make all subsections nest progressively from one unique concept or upper concept.

11. Do not mix up "branches" and "leaves". A concept can't act both as an upper concept and a sub concept (exceptionally it can include a copy of itself).

12. Avoid the mirror effect. Do not focus attention only on those concepts that are easily identifiable equivalents in the surface by leaving out anything that can have idiosyncratic form.

\section{Summary}

Going from human intelligence to artificial intelligence and then taking the way back, we can understand better the processes at the mind of specialized translation students and see it as a neural network process. Our aim is to train students either to translate or post-edit specialized texts ${ }^{1}$. "MT systems primarily make two types of errors - lexical and reordering errors" [6] and our students might be well prepared to go through the lexical level with a hidden conceptual background.

\section{References}

[1] AGUILAR-AMAT, Anna, MESA-LAO, Bartolomé, PAHISA-SOLÉ, Marta (2011): Construir per aprendre: BACUS-UAB o la formació terminològica per a traductors. Terminalia, núm. 4, p. 7-18, Revista de l'Institut d'Estudis Catalans, Gener 2012. http://terminalia.iec.cat,DOI: 10.2436/20.2503.01.26

[2]ANDRADE, Salvador \& FERNÁNDEZ, Margarita (1997). Diagramas conceptuales. Una estrategia de Enseñanza Aprendizaje en el Sistema Modular. En Globalización: industria y sector agrario en México México DF: UAM-X, CSH, Depto. de Producción Económica; 1997. http://andrader0.tripod.com/docs/facilitacion/diagramas.pdf

[3] BACUS (2010): Base de Coneixement UniverSitari), Facultat de Traducció, d'Interpretació i d'Estudis d'Àsia Oriental (FTIEAO), 1999-2010, http://www.fti.uab.es/departament/BACUS/index_es.htm

[4] FABER, Pamela (2011). The dynamics of specialized knowledge representation: Simulational reconstruction or the perception-action interface. Terminology 17, no. 1 (January 1): 9-29. <http://dx.doi.org/10.1075/term.17.1.02fab> [last visit: 11/02/2016]

[5] NOVAK, Josep D. (2004): Concept Maps: Theory, Methodology, Technology, Proceedings of the First International Conference on Concept Mapping, Pamplona, Spain (September 14-17, 2004). With A.J. Cañas, and Fermin M. González (Eds.). Editorial Universidad Pública de Navarra.

[6] PAL, Santanu, NASKAR, Sudip Kumar, VELA, Mihaela, VAN GENABITH, Josef (2016): A Neural Network based Approach to Automatic Post-Editing. Proceedings of the 54th Annual Meeting of the Association for Computational Linguistics, pages 281-286, Berlin, Germany, August 7-12, 2016. c 2016 Association for Computational Linguistics. http://www.aclweb.org/anthology/P16-2046

\footnotetext{
${ }^{1}$ This work is developed under the Project ProjecTA ( Proyectos de traducción con Traducción Automática Estadística y Posedición ), funded by the Ministry of Economy and Competitiveness, Reference FFI2013-46041-R.
} 